Publisher homepage:www.universepg.com, ISSN: 2663-7820 (Online) \& 2663-7812 (Print)

https://doi.org/10.34104/cjbis.020.01290140

Canadian Journal of Business and Information Studies

UniversePG

Journal homepage:http://www.universepg.com/journal/cjbis

\title{
Evaluation and Comparison of Financial Soundness of Islamic and Conventional Private Commercial Banks in Bangladesh: A CAMEL Approach
}

\author{
Aslam Mahmud ${ }^{1 * a n d ~ M d . ~ H a b i b u r ~ R a h m a n ~}{ }^{2}$ \\ ${ }^{1 \& 2}$ Department of Finance and Banking, Faculty of Business Administration, Jatiya Kabi Kazi Nazrul Islam University \\ (JKKNIU), Trishal, Mymensingh-2220, Bangladesh. \\ *Correspondence: aslammahmudknu@gmail.com (Aslam Mahmud, Lecturer, Department of Finance and Banking, Faculty \\ of Business Administration, JKKNIU, Trishal, Mymensingh-2220, Bangladesh).
}

\begin{abstract}
This article evaluates and compares the financial soundness of Islamic and conventional PCBs operating in Bangladesh based on the CAMEL approach over the period 2015 to 2019. For this purpose, the authors select a sample of 17 Conventional PCBs and 6 Islamic PCBs listed on the Dhaka Stock Exchange. In terms of composite CAMEL ratings, none of the banks is found to be strong or satisfactory in financial soundness in 2019. Out of 17 conventional banks, 13 of them are in a fair position i.e. having financial, operational, or compliance weakness and need more than normal supervision and regulation to address the deficiencies. Another 4 conventional banks are in a marginal position means that they are in serious financial problems and need close supervision and regulation. Ranking of conventional banks based on composite CAMEL ratings shows that Brac Bank Ltd. is in top position (Score 2.65) with Bank Asia Ltd. securing second position (score 2.7) while AB Bank Ltd., IFIC Bank Ltd, One Bank Ltd., and Mutual Trust Bank Ltd. are in the worst position with marginal status. Among 6 Islamic banks, 5 are in a fair position and only 1 in a marginal position in 2019. Shahjalal Islami Bank Ltd. secures the top position (Score 2.8) with fair status and Social Islami Bank Ltd. is in the worst position with marginal status. Independent sample test is used to see whether there is any significant difference between Islamic and Conventional PCBs concerning CAMEL parameters. The study finds that except for liquidity there is no significant difference in capital adequacy, asset quality, management quality, and earnings quality. The study also reveals that there is no significant difference in the average CAMEL ratings of two types of Banking. However, on average Islamic banks have better asset quality, management quality while conventional banks have better capital adequacy, earnings, and liquidity.
\end{abstract}

Keywords: CAMEL rating, Independent sample test, Marginal, Financial soundness, and Asset quality.

\section{INTRODUCTION:}

According to the Organization of Islamic Cooperation (OIC) "Islamic banks is a financial institution whose status, rules and procedures expressly state its commitment to the principles of Islamic Shariah and the banning of the receipt and payment of interest on any UniversePG lwww.universepg.com of its operations." The first Islamic bank in the modern worldwas established in Egypt named Mit-ghamr saving bank. But it was closed in1967 due to political reasons. In the second attempt, Nasser Social Bank was established in 1971 in Egypt. In 1975, the Islamic Development Bank (IDB) was established in Saudi 
Arabia. In the same year, Dubai Islami Bank was established in the United Arab Emirates (UAE). Today there are more than 300 banks around the world that comply with Islamic shariah. ${ }^{\mathrm{i}}$ Islamic banks operate in more than 67 countries of the world with assets of more than 2.8 trillion dollars. Islamic banks present an alternative and attractive source of financing in Muslim majority and minority countries and ensure stable and sustainable growth (Gazi, 2020).The first Islami bank in Bangladesh is Islami Bank Bangladesh Limited (IBBL) established on 30 March 1983. Till today there are 8 full-fledged Islamic banks and 17 conventional banks with Islamic banking branches or Islamic banking windows. Islamic banking industry accounts for one-fourth share of total deposit and investment of the entire banking industry at the end of the first quarter of 2019. ii

The most widely used and popular method for checking the financial health of banks is the CAMELS rating system. The six alphabets of CAMELS indicate Capital adequacy, Asset quality, Management quality, Earnings quality, Liquidity, and Sensitivity to market risk. Evaluating each of these factors, a composite index can be formed to measure the overall financial health of a bank or a set of banks. Regulators use this rating system to identify banks requiring special regulatory attention.

This study measures and compare the financial health of Islamic private commercial banks and conventional private commercial banks based on CAMEL analysis. Each type of bank was ranked according to its CAMEL rating and financial status is assigned according to its financial soundness measured by CAMEL model. Average CAMEL rating scores were also calculated and compared over the study period to know whether there is any significant difference in Capital adequacy, Asset quality, Management quality, Earnings quality, Liquidity, and overall composite score between Islamic banks and conventional banks. The study will help all stakeholders including bank managers, investors depositors, policymakers, and regulators in identifying financial soundness and status of banks to predict which banks are in financial difficulty and needs immediate corrective actions. This study also helps stakeholders in comparing the

UniversePG I www.universepg.com financial soundness of conventional banks and Islamic banks operating in Bangladesh.

\section{Review of Literature}

Various studies have been conducted to date to compare the performance of Islamic banks and conventional banks based on the Camel model. Some of the reviews of previous studies are discussed below:

A study by Naeem, (2016) explores the comparative financial performance of Islamic and conventional banks. He collects secondary data from five conventional banks and five Islamic banks throughout 2008-2015. One-way ANOVA was used to indicate the distinction between conventional banks and Islamic banks in every field of CAMEL and fields of CAMEL was also regressed against financial performance indicators. Their findings showed that Islamic banks over-performed conventional banks in terms of capital adequacy, management efficiency, asset quality, and liquidity. Whereas conventional banks beat Islamic banks in terms of procuring capacity. In a study, Akber and Dey, (2020) compared the performance of Islamic banks and conventional banks based on the CAMEL test. They selected five conventional banks and five Islamic banks to collect secondary data from respective bank website for 2015 to 2020. They measured every parameter of the CAMEL test based on appropriate ratios and used a t-test to show whether there is any significant difference. The empirical result showed that except for management quality there is no significant difference between Islamic banks and conventional banks in the CAMEL parameter. Quality of management and asset quality of Islamic banks are better than conventional banks whereas capital adequacy and liquidity condition are better for conventional banks.

In a study, Akala, (2018) assessed and compared the financial performance of both participation banks and conventional banks in turkey for 2005-2015. He made a comparison of financial performance judging the balance sheets, income statements, asset, equity, deposit, profitability, loan, capital adequacy, and some other ratios of both participation and conventional banks. The study found that conventional banks are performing better than conventional banks in terms of profitability whereas participation banks are growing 
fast than conventional banks with greater stability. In his study, Ahsan, (2016) evaluates the financial soundness of selected three Islamic banks in Bangladesh from 2007 to 2014. He used the CAMEL approach to performance evaluation. For this purpose, he calculated six ratios to measure every parameter of CAMEL. He found that each of the three banks namely Islami bank Bangladesh limited, Exim bank limited, and Shahjalal Islami bank limited are in a strong position in financial soundness according to CAMEL parameters.

Hawaldar et al. (2017) compared the financial performance of Islamic banks and conventional banks in Bahrain. They collected secondary data from 19 Islamic banks and 13 conventional banks. Ratio analysis and trend analysis are used to compare the performance of Islamic banks and conventional banks in terms of profitability, liquidity, solvency, commitment, and productivity. The study covers a period of five years from 2010 to 2014. The empirical evidence showed that there is no significant difference in performance between Islamic and conventional banks. The study also showed that wholesale banks are performing better than the retail bank both in interestfree and interest-based format. In a study, Kumar and Sayani, (2015) carried their analysis to find out the safety and soundness of Islamic banks operating in GCC countries for 2008-2014 to cover the period of crisis and post-crisis period. They collect data based on a sample of 11 Islamic banks selected based on the availability of data. The researchers calculated ratios needed to perform CAMEL analysis and emerging economy Z score analysis. From CAMEL Analysis they found that these Islamic banks have enough capital but asset quality and earning ability are deteriorating over the period during the period of this analysis. From $\mathrm{Z}$ score analysis they found that score of all of the banks is above 2.6 confirming their financial resilience despite the financial crisis (Azim and Sharif, 2020).

In her study, Akter, (2016) compares the CAMELS rating of State-owned commercial banks (SCBs), Development financial institutions (DFIs), Private commercial banks (PCBs), and foreign commercial banks (FCBs) operating in Bangladesh. Her secondary data-based study covers a period from 2006 to 2013. UniversePG I www.universepg.com
The study found that no bank was rated 1 or strong, 28 banks were rated 2 or satisfactory, 12 banks were rated 3 or fair, 6 banks were rated 4 or marginal and only 1 bank was rated 1 or unsatisfactory. Another study by Hossain et al. (2017) comparesthe performance of Islamic banks and conventional banks based onthe Camel model. For this purpose, they select five conventional private commercial banks and five Islamic private commercial banks. Their study is based on secondary data and covers a period from 2011 to 2015. They applied an independent sample test to find out whether there is any significant difference between Islamic banks and conventional banks concerning Camel parameters. Their study found that there is no significant difference in capital adequacy, asset quality, management quality, and earnings quality between Islamic banks and conventional banks. However, Islamic banks are significantly less liquid than conventional banks.

Some other studies conducted by Mohiuddin (2016); Rahman \& Islam (2018); Rafiq (2016); Sarker (2016); Islam \& Ashrafuzzaman (2015) measure and compare the financial soundness of banks operating in Bangladesh.

\section{Hypotheses of the Study}

The study includes the following hypotheses to be tested:

H1: There is no significant difference between conventional banks and Islamic banks in terms of capital adequacy.

$\mathrm{H} 2$ : There is no significant difference between conventional banks and Islamic banks in terms of asset quality.

H3: There is no significant difference between conventional banks and Islamic banks in terms of management quality.

H4: There is no significant difference between conventional banks and Islamic banks in terms of Earnings Quality.

H5: There is no significant difference between conventional banks and Islamic banks in terms of liquidity.

H6: There is no significant difference in CAMEL ratings between conventional banks and Islamic banks. 


\section{Data and Sample}

A total number of 30 banks are listed in Dhaka Stock Exchange (DSE) which includes 22 conventional private commercial banks, 1 conventional state-owned commercial banks, and 7 Islamic private commercial banks. The sample of the study includes 17 conventional private commercial banks and 6 Islamic private commercial banks listed in DSE. A purposive sampling technique was followed in the selection of banks. The study is completely secondary data based. Data were collected from the annual reports of sample banks over 5 years i.e. 2015 to 2019. So the sample includes a total number of 125 observations.

\section{METHODOLOGY:}

In this study, total capital to total risk-weighted asset ratio, non-performing loan to total asset ratio, the cost to income ratio, net interest margin ratio, and loan to deposit ratio is calculated to measure each parameter of CAMEL model (C for Capital Adequacy, A for Asset quality, $\mathrm{M}$ for Management quality, $\mathrm{E}$ for Earnings quality and L for Liquidity). An Independent sample test was used to show whether there is a significant difference between conventional banks and Islamic banks concerning each parameter of CAMEL model. Ratios calculation was done using Excel spreadsheets and an Independent sample test for comparing the mean was done through SPSS (Statistical Package for Social Science) version 26. In calculating the CAMEL score, a rating of 1 to 5 was assigned to each component (1 indicates best and 5 indicates worst) of CAMEL model. Then weight was assigned to each component and the weighted rating was calculated. Finally, the weighted rating of each component was summed up to calculate the composite CAMEL score.

Table 1: CAMEL rating framework

\begin{tabular}{|c|c|c|c|c|c|c|c|}
\hline Component & Ratio & Weight & 1 & 2 & 3 & 4 & 5 \\
\hline $\begin{array}{l}\text { C for Capital } \\
\text { Adequacy }\end{array}$ & $\begin{array}{l}\text { Total Capital/Total risk- } \\
\text { weighted assets (CAR) }\end{array}$ & .20 & $\geq 15 \%$ & $12 \%-14.99 \%$ & $8 \%-11.99 \%$ & $7 \%-7.99 \%$ & $\leq 6.99 \%$ \\
\hline $\begin{array}{l}\text { A for Asset } \\
\text { Quality }\end{array}$ & $\begin{array}{c}\text { Nonperforming } \\
\text { loans/Total assets (NPL) }\end{array}$ & .25 & $<3 \%$ & $3 \%-<5 \%$ & $5 \%-<10 \%$ & $10 \%-<15 \%$ & $\geq 15 \%$ \\
\hline $\begin{array}{c}\text { M for } \\
\text { Management } \\
\text { Soundness }\end{array}$ & $\begin{array}{l}\text { Cost to income ratio } \\
\text { (CIR) }\end{array}$ & .25 & $\leq 25 \%$ & $30 \%-26 \%$ & $38 \%-31 \%$ & $45 \%-39 \%$ & $\geq 46 \%$ \\
\hline E for Earnings & Return on equity (ROA) & .20 & $\geq 1.3 \%$ & $.8 \%-<1.3 \%$ & $.4 \%-<.8 \%$ & $.16 \%-<.4 \%$ & $<.16 \%$ \\
\hline L for Liquidity & $\begin{array}{l}\text { Loan to deposit ratio } \\
\text { (LDR) }\end{array}$ & .10 & $\leq 55 \%$ & $62 \%-56 \%$ & $68 \%-63 \%$ & $80 \%-69 \%$ & $\geq 81 \%$ \\
\hline
\end{tabular}

Source: (Masood et al., 2016; Huq, 2017; Reddy, 2012)

Composite CAMEL ratings are divided into five categories. According to the composite CAMEL ratings, the financial soundness of a bank can be described as strong, satisfactory, fair, marginal, or unsatisfactory.
The range of composite rating, an indication of financial status, and their meaning in terms of financial health are described in Table 2.

Table 2: Meaning of composite rating under CAMEL rating analysis

\begin{tabular}{|c|c|l|l|}
\hline Rating & Composite range & \multicolumn{1}{|c|}{ Status } & \multicolumn{1}{c|}{ Meaning } \\
\hline 1 & $1.00-1.49$ & Strong & Sound in every aspect and no cause for regulatory concern. \\
\hline 2 & $1.50-2.49$ & Satisfactory & \begin{tabular}{l} 
Fundamentally sound and regulatory concerns are limited. \\
\hline 3
\end{tabular} \\
$2.50-3.49$ & Fair & $\begin{array}{l}\text { Financial, operational, or operational weakness ranging from } \\
\text { moderately severe to unsatisfactory. } \\
\text { Therefore the regulatory concern and more than normal supervision } \\
\text { is needed to address the deficiency }\end{array}$ \\
\hline 4 & $3.50-4.49$ & Marginal & $\bullet \quad$ Serious financial weakness and a high potential for failure. \\
\hline
\end{tabular}




\begin{tabular}{|c|c|c|c|}
\hline & & & $\begin{array}{l}\text { - Close supervision and a definite plan for correcting deficiency are } \\
\text { needed. }\end{array}$ \\
\hline 5 & $4.50-5.00$ & Unsatisfactory & $\begin{array}{l}\text { - High immediate or near term probability of failure } \\
\text { - Immediate corrective actions are needed to prevent liquidation, } \\
\text { merger, or acquisition. }\end{array}$ \\
\hline
\end{tabular}

Source: (Khan,2008)

\section{ANALYSIS AND RESULTS:}

Table 3 shows the CAMEL ratings of conventional private commercial banks. The rating shows that no bank included in the sample is in a strong or satisfactory financial condition in 2019. Only AB Bank Ltd. was in an unsatisfactory condition in 2018 which turned into marginal in 2019. The worst condition for AB Bank Ltd. is mainly for high nonperforming loans (33\% in 2018 and 18\% in 2019). Besides AB Bank Ltd., IFIC Bank ltd., Mutual Trust Bank Ltd. and One Bank Ltd. are in marginal status 2019. That means that these banks have problems in asset quality, management quality, capital adequacy, or liquidity. Regulators should have a close supervisory look on these banks and take corrective actions to prevent further
deterioration.Thirteen banks out of sample banks were assigned fair status. Among them Brac bank ltd. is in the top position (Score 2.65) mainly due to high capital adequacy $(16.16 \%)$, low level of nonperforming loans (3.99\%), and higher earnings (ROA $1.53 \%$ ) in 2019. Bank Asia and Eastern Bank secure the second position with a CAMEL score of 2.70 . However fair position in financial soundness is not a risk-free position. A moderate level of financial, operational, or compliance weakness may exist. Regulatory concern and extra supervision are needed in correcting deficiencies and preventing weaknesses from further deterioration (Khan, 2008). Table 3 shows the CAMEL score and financial status of conventional banks for the study period.

Table 3: CAMEL ratings of conventional PCBs

\begin{tabular}{|c|c|c|c|c|c|c|c|c|c|c|c|}
\hline \multirow{3}{*}{ BankName } & \multicolumn{8}{|c|}{ Composite Rating } & \multirow{3}{*}{$\begin{array}{l}\text { Avg. } \\
\text { Score }\end{array}$} & \multirow{3}{*}{$\begin{array}{l}\text { Avg. } \\
\text { Rank }\end{array}$} & \multirow{3}{*}{$\begin{array}{l}\text { Avg. } \\
\text { Status }\end{array}$} \\
\hline & \multicolumn{3}{|l|}{2019} & \multicolumn{2}{|l|}{2018} & \multirow{2}{*}{$\begin{array}{c}2017 \\
\text { Score }\end{array}$} & \multirow{2}{*}{$\begin{array}{l}2016 \\
\text { Score }\end{array}$} & \multirow{2}{*}{$\begin{array}{l}2015 \\
\text { Score }\end{array}$} & & & \\
\hline & Score & Status & Rank & Score & Status & & & & & & \\
\hline Trust Bank & 3 & Fair & 7 & 3 & Fair & 3 & 2.8 & 3 & 2.96 & 5 & Fair \\
\hline Pubali Bank & 3.15 & Fair & 11 & 3.3 & Fair & 3.9 & 3.7 & 3.4 & 3.49 & 15 & Fair \\
\hline Mutual Trust & 3.5 & Marg. & 14 & 3.5 & Marg. & 3.05 & 3.15 & 2.8 & 3.2 & 10 & Fair \\
\hline MerchnBank & 3 & Fair & 7 & 3.05 & Fair & 3 & 3.3 & 3.35 & 3.14 & 8 & Fair \\
\hline City Bank & 3.2 & Fair & 12 & 3.5 & Marg. & 3.1 & 3.1 & 3 & 3.18 & 9 & Fair \\
\hline Dutch Bangla & 2.75 & Fair & 4 & 2.75 & Fair & 3.15 & 3.4 & 3.05 & 3.02 & 6 & Fair \\
\hline Premier Bank & 3.05 & Fair & 9 & 3.05 & Fair & 3.05 & 3.3 & 3.7 & 3.23 & 11 & Fair \\
\hline Dhaka Bank & 2.8 & Fair & 5 & 3 & Fair & 3.45 & 3 & 3.25 & 3.1 & 7 & Fair \\
\hline UCB & 3.25 & Fair & 13 & 3.4 & Fair & 3.5 & 3.6 & 3.1 & 3.37 & 13 & Fair \\
\hline ABBank & 4.35 & Marg. & 17 & 4.6 & Unsatis. & 4.1 & 3.7 & 3.45 & 4.04 & 17 & Marg. \\
\hline BracBank & 2.65 & Fair & 1 & 2.65 & Fair & 3.05 & 2.85 & 3.3 & 2.9 & 3 & Fair \\
\hline IFIC & 3.5 & Marg. & 14 & 3.5 & Marg. & 3.3 & 3.7 & 3.7 & 3.54 & 16 & Marg. \\
\hline BankAsia & 2.7 & Fair & 2 & 2.8 & Fair & 3 & 3.15 & 2.7 & 2.87 & 2 & Fair \\
\hline SouthEast & 2.95 & Fair & 6 & 3 & Fair & 3.4 & 2.55 & 2.75 & 2.93 & 4 & Fair \\
\hline One Bank & 3.5 & Marg. & 14 & 3.7 & Marg. & 3.5 & 3.05 & 3.25 & 3.4 & 14 & Fair \\
\hline Prime Bank & 3.05 & Fair & 9 & 3.3 & Fair & 3.7 & 3.2 & 3.2 & 3.29 & 12 & Fair \\
\hline Eastern Bank & 2.7 & Fair & 2 & 2.8 & Fair & 2.8 & 2.35 & 3.05 & 2.74 & 1 & Fair \\
\hline
\end{tabular}


Table 4 shows the CAMEL ratings of Islamic PCBs. It shows out of 6 sample banks only Social Islami bank Ltd. (SIBL) was in marginal status in 2019. The remaining five banks were in fair status. Shah Jalal Islami bank Ltd. was in top position with the least CAMEL score (2.80) in 2019. Shah Jalal Islami Bank Ltd. was in marginal status in2018 but had been able to lower the level of nonperforming loans, increase capital adequacy, and moderate the level of cost to income ratio. Al-Arafah Islami Bank Ltd. was in the second position with a CAMEL score of 3.0. However, all the banks need close supervision and surveillance from regulators to overcome weaknesses and secure a strong or satisfactory position ensuring sound financial health. Table 4 below shows the CAMEL score and related status of sample banks for the study period.

Table 4: CAMEL rating of Islamic PCBs

\begin{tabular}{|c|c|c|c|c|c|c|c|c|c|c|c|}
\hline \multirow{3}{*}{ Bank Name } & \multicolumn{8}{|c|}{ Composite Rating } & \multirow{3}{*}{$\begin{array}{l}\text { Avg. } \\
\text { Score }\end{array}$} & \multirow{3}{*}{$\begin{array}{l}\text { Avg. } \\
\text { Status }\end{array}$} & \multirow{3}{*}{$\begin{array}{l}\text { Avg. } \\
\text { Rank }\end{array}$} \\
\hline & \multicolumn{3}{|c|}{2019} & \multicolumn{2}{|c|}{2018} & \multirow{2}{*}{$\begin{array}{l}2017 \\
\text { Score }\end{array}$} & \multirow{2}{*}{$\begin{array}{l}2016 \\
\text { Score }\end{array}$} & \multirow{2}{*}{$\begin{array}{l}2015 \\
\text { Score }\end{array}$} & & & \\
\hline & Score & Status & Rank & Score & Status & & & & & & \\
\hline IBBL & 3.25 & Fair & 3 & 3.45 & Fair & 3.45 & 3.45 & 3.45 & 3.41 & Fair & 6 \\
\hline Al-Arafah & 3 & Fair & 2 & 3.25 & Fair & 2.8 & 2.55 & 2.35 & 2.79 & Fair & 1 \\
\hline EXIM Bank & 3.25 & Fair & 3 & 3.45 & Fair & 3.3 & 3.5 & 3 & 3.3 & Fair & 4 \\
\hline FIRSTSBank & 3.45 & Fair & 5 & 3.45 & Fair & 3.25 & 3.2 & 3.4 & 3.35 & Fair & 5 \\
\hline SIBL & 3.5 & Marg. & 6 & 3.5 & Marg. & 3.45 & 3 & 2.8 & 3.25 & Fair & 3 \\
\hline SHAHAJBank & 2.8 & Fair & 1 & 3.5 & Marg. & 3.25 & 3.25 & 3.3 & 3.22 & Fair & 2 \\
\hline
\end{tabular}

\subsection{Conventional PCBs vs Islamic PCBs-A com- parison}

Capital Adequacy - Capital adequacy measures the ability of a bank to protect depositors, creditors, and other stakeholders from the credit, market, and operational risk that the bank might faces. According to Basel-III, banks in Bangladesh are required to fulfill a minimum capital requirement of $10 \%$ or 5 billion which is higher. ${ }^{\text {iii }}$ Fig 1 shows the trend of capital adequacy over the five years for Islamic and conventional banks. From mid-2015, capital adequacy is higher for conventional banks and this trend analysis also shows the capital adequacy ratio is increasing for both Islamic andconventional banks. Both Islamic and conventional banks have a similar trend of capital adequacy over this period. Table 5 shows that the mean capital adequacy ratio of conventional banks and Islamic banks is $12.94 \%$ and $12.61 \%$ respectively. This indicates that both conventional private commercial banks and Islamic private commercial banks maintain capital enough to fulfill the minimum requirement.

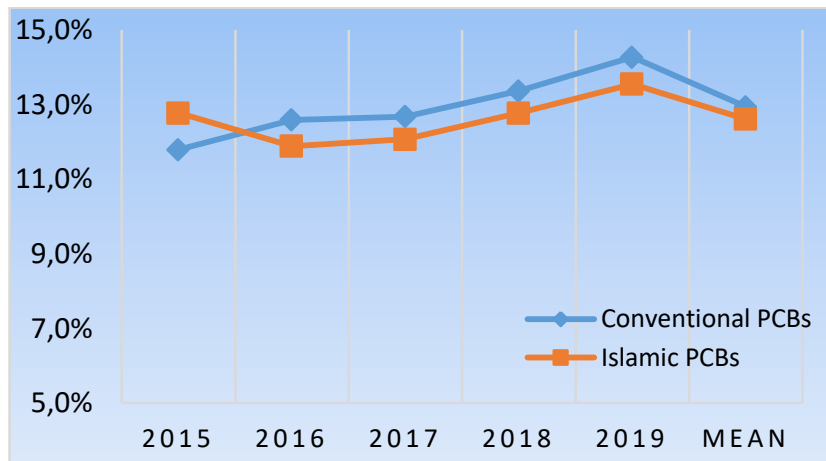

Fig 1: Trend analysis of capital adequacy ratio.

Table 6 shows that the p-value of Levene's Test for equality of variance is greater than $5 \%(.989>.05)$. So equality of variance is not rejected. It also shows that the p-value of the t-test for equality of means is higher than $0.05(0.366>0.05)$. It is not rejected $(\mathrm{H} 1)$ that there is no significant difference between Conventional PCBs and Islamic PCBs in terms of capital adequacy. So it can be said that although the mean capital adequacy ratio is higher for Islamic PCBs, this difference is statistically significant.

Table 5: Group Statistics

\begin{tabular}{|l|l|l|l|l|l|}
\hline \multirow{3}{*}{ CAR } & Bank Type & N & Mean & Std. Deviation & Std. Error Mean \\
\cline { 2 - 6 } & Conventional PCBs & 85 & 0.129387 & 0.017267 & 0.001873 \\
\cline { 2 - 6 } & Islamic PCBs & 30 & 0.126097 & 0.016554 & 0.003022 \\
\hline
\end{tabular}


Table 6: Independent Sample Test

\begin{tabular}{|l|l|l|l|l|l|l|l|}
\hline \multirow{2}{*}{ CAR } & \multicolumn{2}{|c|}{$\begin{array}{c}\text { Levene's Test for } \\
\text { Equality of Variances }\end{array}$} & \multicolumn{3}{l|}{ t-test for Equality of Means } \\
\cline { 2 - 10 } & F & Sig. & t & df & Sig. & Lower & Upper \\
\hline Equal variances assumed & 0 & 0.989 & 0.907 & 113 & 0.366 & -0.0039 & 0.010479 \\
\hline Equal variances not assumed & & 0.925 & 52.859 & 0.359 & -0.00384 & 0.010422 \\
\hline
\end{tabular}

Asset Quality - Asset quality indicates how much nonperforming and risky assets a bank has as a percentage of total assets. The most commonly used measure of asset quality is the ratio of non-performing loans (NPLs) to total assets. Fig $\mathbf{2}$ shows that the nonperforming loan ratio is always higher for conventional banks. Asset quality deteriorates much in 2018 for conventional banks and then it had been able to reduce the severity to some extent in 2019 . Both types of banks show a decreasing trend in asset quality from 2016 and it slightly improves in 2019.

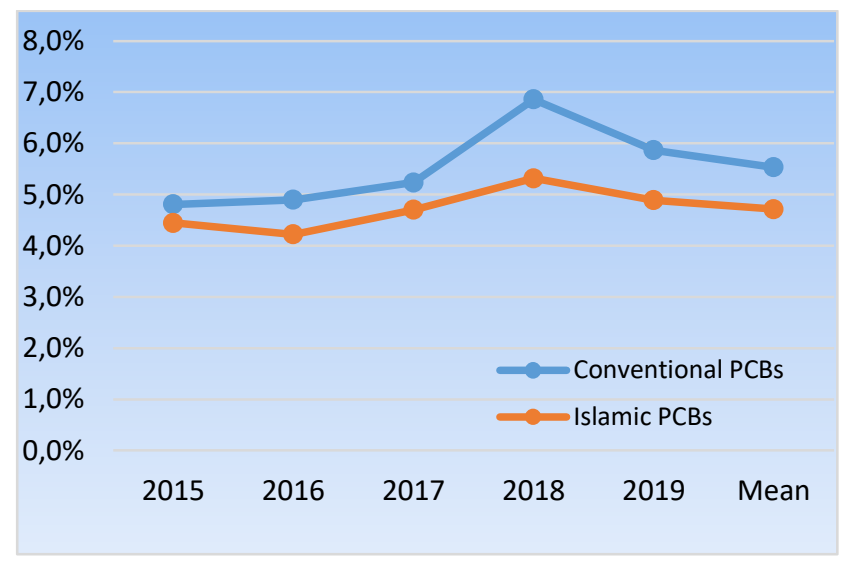

Fig 2: Trend analysis of non-performing loan ratio.
Table 7 shows that the mean nonperforming loan ratio for Conventional PCBs is $5.53 \%$ and $4.70 \%$ for Islamic PCBs. From the values of standard deviation, it can be stated that the variability of the nonperforming loan ratio is higher among Conventional PCBs than Islamic PCBs. So, on average, the asset quality of Islamic PCBs is better than Conventional PCBs.

Table 8 shows the independent sample test. The pvalue from Levene's test for equality of variance indicates that the assumption of the equality of variance is not rejected. The t-test for equality of means indicates that Asset quality does differ significantly between Conventional PCBs and Islamic PCBs. So, the null hypothesis (H2) of equality of asset quality is not rejected.

Management Quality - Management quality measures the soundness of management. It is the most subjective parameter of the CAMEL model. Successful management is the ability of management to keep costs significantly below income (Shah, 2014). Cost to income ratio is an important indicator of management quality.

Table 7: Group Statistics

\begin{tabular}{|l|l|l|l|l|l|}
\hline & Bank Type & $\mathbf{N}$ & Mean & Std. Deviation & Std. Error Mean \\
\hline \multirow{2}{*}{ NPL } & Conventional PCBs & 85 & .0553282 & .03648096 & .00395692 \\
\cline { 2 - 6 } & Islamic PCBS & 30 & .0471467 & .01335225 & .00243778 \\
\hline
\end{tabular}

Table 8: Independent Sample Test

\begin{tabular}{|l|l|l|l|l|l|l|l|}
\hline & \multicolumn{2}{|l|}{$\begin{array}{c}\text { Levene's Test for Equality } \\
\text { of Variances }\end{array}$} & \multicolumn{3}{l|}{ t-test for Equality of Means } \\
\hline NPL & F & Sig. & t & df & Sig. & Lower & Upper \\
\cline { 2 - 9 } & 1.38 & 0.243 & 1.197 & 113 & 0.234 & -0.00535 & 0.021717 \\
\hline
\end{tabular}


Fig 3 shows the trend of cost to income ratio is always higher for conventional banks over this period but it has managed to reduce the ratio from $49.96 \%$ in 2018 to $48.3 \%$ in 2019 . This is a signal for improving management quality in conventional banks.

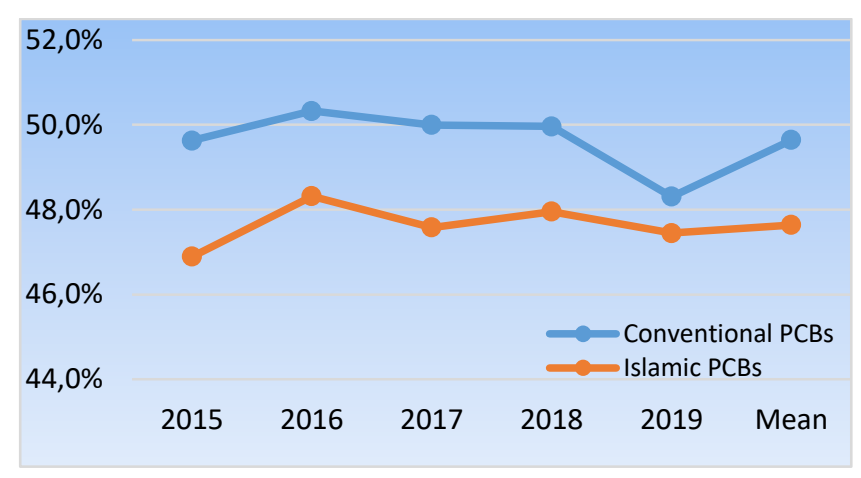

Table 9 shows that the mean cost to income ratio is $49.64 \%$ for Conventional PCBs and $47.63 \%$ for Islamic PCBs. This indicates that on average management quality of Islamic PCBs is better over this period.

Table 10 shows that the null hypothesis of approximately equal variances is not rejected (P>.05). The t-test for equality of means shows that the difference in management quality evaluated by cost to income ratio between Conventional PCBs and Islamic PCBs is not statistically significant $(0.191 .>0.05)$. So the hypothesis $(\mathrm{H} 3)$ of equality of management quality between Islamic and Conventional PCBs is not rejected.

Fig 3: Trend analysis of cost to income ratio

Table 9: Group statistics

\begin{tabular}{|l|l|l|l|l|l|}
\hline & Bank Type & N & Mean & Std. Deviation & Std. Error Mean \\
\hline \multirow{2}{*}{ CIR } & Conventional PCBS & 85 & .4964306 & .07637528 & .00828406 \\
\cline { 2 - 6 } & Islamic PCBS & 30 & .4763900 & .05649138 & .01031387 \\
\hline
\end{tabular}

Table 10: Independent sample test

\begin{tabular}{|l|l|l|l|l|l|l|l|}
\hline \multirow{2}{*}{ CIR } & \multicolumn{9}{|c|}{$\begin{array}{c}\text { Levene's Test for } \\
\text { Equality of Variances }\end{array}$} & \multicolumn{3}{l|}{ t-test for Equality of Means } \\
\cline { 2 - 9 } & F & Sig. & t & df & Sig. & Lower & Upper \\
\cline { 2 - 9 } Equal variances assumed & 3.536 & 0.063 & 1.314 & 113 & 0.191 & -0.01017 & 0.050249 \\
\hline Equal variances not assumed & & & 1.515 & 68.626 & 0.134 & -0.00635 & 0.046434 \\
\hline
\end{tabular}

Earnings Quality - Return on Asset (ROA), Return on Equity (ROE), and Net Interest Margin (NIM) are the most frequently used measure of earnings and profitability. In this study Return on Asset (Net Income/Total assets) has been used as a measure of earnings quality. Fig 4 shows that earnings quality is always better for conventional banks. However, both banks show a declining trend over the study period.

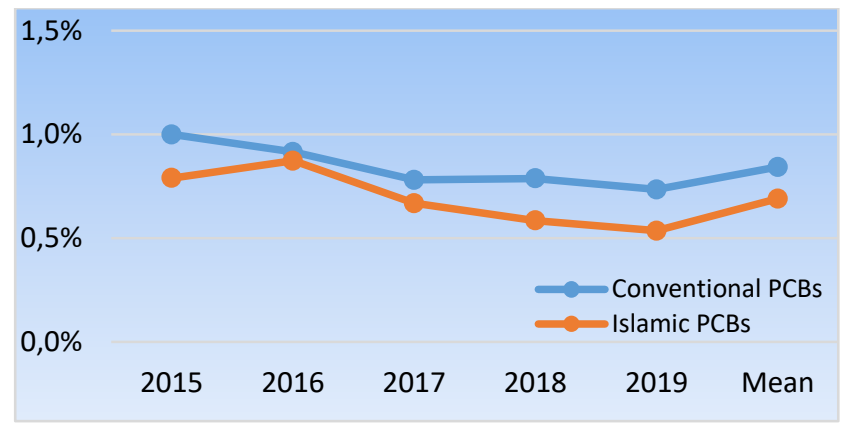

Fig 4: Trend analysis of return on asset ratio.
Table 11 shows that the mean net interest margins are 2.39\% for Conventional PCBs and 2.64\% for Islamic PCBs. From the values of Standard deviation, it can be said that the variability of earnings quality is much higher for Conventional PCBs. So on average Islamic PCBs have better earnings quality than Conventional counterparts

Table 12 shows the results of the independent sample test. Levene's test for equality of variances shows that the null hypothesis of equal variances is rejected ( $\mathrm{p}$ value < 0.05). The result of the t-test for equality of variance shows that we do not reject the null hypothesis $(\mathrm{H} 4)$ that there is no significant difference in the earnings quality between Conventional and Islamic PCBs at a 5\% level of significance. At a $10 \%$ level of significance, the hypothesis of no difference in earning quality is rejected. 
Table 11: Group statistics

\begin{tabular}{|l|l|l|l|l|l|}
\hline & Bank Type & N & Mean & Std. Deviation & Std. Error Mean \\
\hline \multirow{2}{*}{ ROA } & Conventional PCBs & 85 & .00843101 & .003853149 & .000417933 \\
\cline { 2 - 6 } & Islamic PCBs & 30 & .00690179 & .002549541 & .000465480 \\
\hline
\end{tabular}

Table 12: Independent sample test

\begin{tabular}{|l|l|l|l|l|l|l|l|}
\hline \multirow{2}{*}{ ROA } & \multicolumn{2}{|c|}{$\begin{array}{c}\text { Levene's Test for Equality } \\
\text { of Variances }\end{array}$} & \multicolumn{2}{|l|}{ t-test for Equality of Means } & Lower & Upper \\
\cline { 2 - 9 } & F & Sig. & t & df & Sig. & & \\
\cline { 2 - 9 } Equal variances assumed & 2.859 & 0.094 & 2.020 & 113 & .046 & .000030 & .0030288 \\
\hline Equal variances not assumed & & & 2.445 & 77.267 & 0.017 & .0002836 & 0.002775 \\
\hline
\end{tabular}

Liquidity - Liquidity indicates a bank's ability to meet cash flow obligations when they arise. Unexpected heavy withdrawal of deposits, loan demand, and other cash needs may force a bank intoa liquidity crisis, often borrowing at a higher interest rate. The measure for liquidity used in thisstudy is the loan to deposit ratio (LDR). Currently, the limits of loan to deposit ratio are $85 \%$ for Convention $\mathrm{PCBs}$ and $90 \%$ for Islamic PCBs. ${ }^{\text {iv }}$ Fig 5 shows that both types of banks had a declining trend of liquidity that slightly improve in 2019.

Table 13 shows that the mean loans to deposit ratio are $82.7 \%$ for Conventional PCBs and $88.9 \%$ for Islamic PCBs. It can be easily stated that on average liquidity measured by loan to deposit ratio is much higher for conventional PCBs.

Table 14 shows the result of the independent sample test. From the results of Levene's test for equality of variances, the null hypothesis of equality of variances is not rejected ( $p$ value $>0.05$ ). The result of the t-test for equality of means shows the hypothesis (H6) of equality of liquidity between Islamic PCBs and Conventional PCBs is rejected ( $\mathrm{P}$ value $<0.05$ ). So, it can be said that the liquidity of Conventional PCBs is significantly higher than that of Islamic PCBs.



Fig 5: Trend analysis of loan to deposit ratio.

Table 13: Group statistics

\begin{tabular}{|l|l|l|l|l|l|}
\hline \multirow{2}{*}{ LDR } & Bank Type & $\mathbf{N}$ & Mean & Std. Deviation & Std. Error Mean \\
\cline { 2 - 6 } & Conventional & 85 & .8270279 & .04686605 & .00508334 \\
\cline { 2 - 6 } & Islamic & 30 & .8890133 & .03342194 & .00610198 \\
\hline
\end{tabular}

Table 14: Independent Sample Test

\begin{tabular}{|c|c|c|c|c|c|c|c|}
\hline \multirow{3}{*}{$\begin{array}{l}\text { LDR } \\
\text { Equal variances assumed }\end{array}$} & \multicolumn{2}{|c|}{$\begin{array}{c}\text { Levene's Test for Equality of } \\
\text { Variances }\end{array}$} & \multicolumn{5}{|c|}{ t-test for Equality of Means } \\
\hline & $\mathrm{F}$ & Sig. & $\mathrm{t}$ & $\mathrm{df}$ & Sig. & Lower & Upper \\
\hline & 1.603 & 0.208 & -6.662 & 113 & 0 & -0.08042 & -0.04355 \\
\hline \multicolumn{3}{|c|}{ Equal variances not assumed } & -7.805 & 71.354 & 0 & -0.07782 & -0.04615 \\
\hline
\end{tabular}


CAMEL Rating - CAMEL model is one of the most important rating systems for measuring the financial soundness of banks. It's a rating system by which regulators can identify the strength and weaknesses of banks and thereby take necessary actions for corrections. CAMEL rating is calculated using the financial statements of banks. In this study, the CAMEL model is used to evaluate and compare the financial soundness of Islamic PCBs and Conventional PCBs. CAMEL rating ranges from 1 to 5 where 1 represents best and 5 represents worst. Fig 6 shows the trends of the CAMEL rating over the study period.The analysis shows anincreasing trend of CAMEL rating for both Conventional PCBs and Islamic PCBs for the study period and this means the financial soundness of both types of banks is declining. However, from 2018, both types of banks started to make a progress in rating.

Group statistics in Table 15 show that the mean CAMEL rating is 3.20 for Conventional PCBs and 3.22 for Islamic PCBs which confirms fair financial soundness for both types of banking (Khan, 2008).

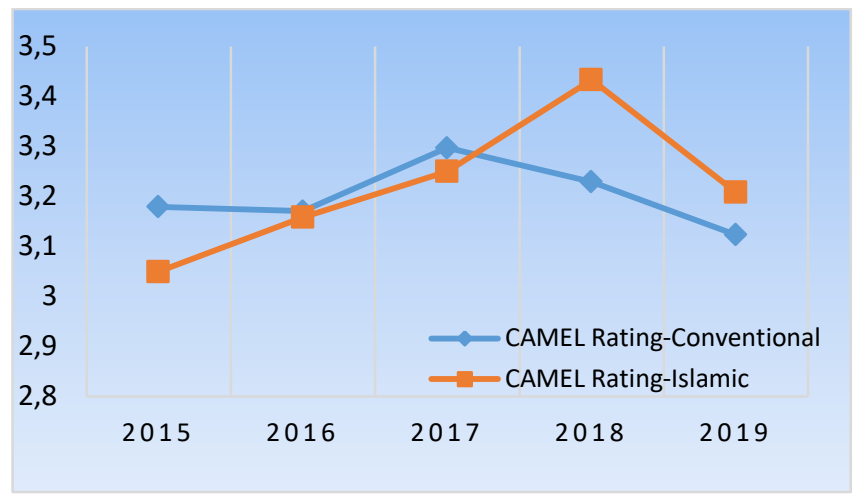

Fig 6: Trend analysis of CAMEL rating.

Levene's Test for Equality of Variances from Table 15 confirms that the assumption of the equality of variance is not rejected (.185>0.05). The result from the t-test for equality of means shows that hypothesis 6 is not rejected $(.798>.05)$ i.e. there is no significant difference in CAMEL ratings between conventional banks and Islamic banks. So, it can be concluded that the financial soundness of conventional banks and Islamic banks is more or less equal.

Table 15: Group statistics

\begin{tabular}{|l|l|l|l|l|l|}
\hline & Bank Type & N & Mean & Std. Deviation & Std. Error Mean \\
\hline \multirow{2}{*}{ CAMEL Ratings } & Conventional PCBs & 85 & 3.20 & .38645212 & .04191662 \\
\cline { 2 - 6 } & Islamic PCBs & 30 & 3.22 & .30331502 & .05537749 \\
\hline
\end{tabular}

Table 16: Independent sample test

\begin{tabular}{|c|l|l|l|l|l|l|l|l|}
\hline \multirow{2}{*}{$\begin{array}{c}\text { CAMEL Rating } \\
\begin{array}{c}\text { Equal variances } \\
\text { assumed }\end{array}\end{array}$} & Levene's Test for Equality of Variances & \multicolumn{2}{|l|}{ t-test for Equality of Means } & Lower & Upper \\
\cline { 2 - 8 } & 0.178 & Sig. & t & df & Sig. & & \\
\hline Equal variances not assumed & 0.185 & -.257 & 133 & 0.798 & -.174372 & .1343729 \\
\hline
\end{tabular}

A summary of the results of t-test for equality of mean of CAMEL analysis between conventional and Islamic private commercial banks:

Table 17: Comparison of Islamic PCBs and Conventional PCBs based onthe CAMEL approach.

\begin{tabular}{|c|c|}
\hline CAMEL Parameters & Results \\
\hline Capital Adequacy & No significant difference \\
\hline Asset Quality & No significant difference \\
\hline Management Quality & No significant difference \\
\hline Earnings & No significant difference \\
\hline Liquidity & $\begin{array}{c}\text { Significant at 5\% level of } \\
\text { significance }\end{array}$ \\
\hline CAMEL Ratings & No significant difference \\
\hline
\end{tabular}

UniversePG I www.universepg.com

\section{CONCLUSION AND RECOMMENDATIONS:}

The banking sector dominates the financial system in Bangladesh. According to ownership structure, scheduled banks in Bangladesh can be classified into State-owned Commercial Banks (SCBs), State-owned Development Financial Institutions (DFIs), Private Commercial Banks (PCBs), and Foreign Commercial Banks (FCBs). Based onthe mode of operation (Conventional and Islamic), Banks in Bangladesh are classified into three categories: Full-fledged Conventional banks, Full-fledged Islamic banks, and Banks with dual mode of operation. ${ }^{\mathrm{v}}$ The Islamic Banking sector in Bangladesh is going under tremendous 
growth due to proper policy supports from regulators and huge public demand since the initiation in 1983. At the end of 2019, there are 8 full-fledged Islamic banks with 1273 branches out of a total of 10578 branches of the whole industry. Moreover, 17 conventional banks are providing Islamic financial services with 19 Islamic banking branches and 88 Islamic banking windows. ${ }^{\text {vi }}$ This study measures and compares the financial health of 6 Islamic PCBs and 17 Conventional PCBs. All of these banks are listed on the DSE From CAMEL ratings of conventional banks, the study found no bank in a strong or satisfactory position whereas 13 banks are in fair status and 4 banks are in marginal status in 2019. Among the 6 Islamic PCBs 5 banks are in fair status and 1 in marginal status. This indicates that the overall health of the banking sector of Bangladesh is not satisfactory and needs close supervision, surveillance, in-time policy support, and corrective actions to address the deficiencies.

The comparative study of financial health based on CAMEL parameters reveals that on average Islamic banks are in a better position compared to conventional banks with respect to asset quality and management quality while conventional banks are in a dominating position in respect of capital adequacy, earnings, and liquidity. However, there is no statistically significant difference between Islamic banks and conventional banks concerning CAMEL parameters except in liquidity measured by total loan to deposit ratio.The independent sample test of CAMEL ratings reveals that although on average CAMEL rating of conventional banks is better than that of Islamic banks, this difference is not statistically significant.The results of this study expected to help all stakeholders including bank managers, policymakers, regulators, depositors, and investors in assessing the financial health and taking necessary effective corrections. This study can be extended to cover all conventional and Islamic banks operating in Bangladesh with a wide range of data.

\section{ACKNOWLEDGMENT:}

The authors would like to thanks those respected authors whose valuable research works havebeen cited in this paper. The authors received no financial support for this research work.

UniversePG I www.universepg.com

\section{CONFLICTS OF INTEREST:}

The authors declared no potential conflicts of interest with any party concerning the research work.

\section{REFERENCES:}

1. Akbar, S.M., and Dey, A. (2020). Evaluation of the Financial Performance between Traditional Private Commercial Banks and Islamic Banks in Bangladesh. International Journal of Islamic Banking and Finance Research, 4(2), PP. 1-10. https://doi.org/10.46281/ijibfr.v4i2.640

2. Akter, R. (2016). Health Check-up of the Commercial Banks in Bangladesh: An Application of CAMELS Model. International J. of Business and Economics Research, 5(2), 2016, 1928. https://doi.org/10.11648/j.ijber.20160502.11

3. Ansari, S., and Rehman, A. (2011). Financial Performance of Islamic and Conventional Banks in Pakistan: A Comparative Study, $8^{\text {th }}$ International Conference on Islamic Economics and Finance, Qatar.

4. Azim M. and Sharif MJ. (2020). Usability of Z score: a case study on people's leasing and financial services limited \& Bangladesh industrial finance company limited, Int. J. Manag. Account. 2(3), 38-46.

https://doi.org/10.34104/ijma.020.038046

5. Dodoev, K. (2018). Comparative Analysis of Islamic and Conventional Banks in Camel Model: In Case of Malaysia. Global Journal of Management and Business Research: C Finance, 18(6), PP. 28-33.

https://doi.org/10.1142/S2424786317500062

6. Gazi MAI. (2020). Islamic perspective of leadership in management; foundation, traits and principles, Int. J. Manag. Account. 2(1), 19. https://doi.org/10.34104/ijma.020.0109

7. Ghazavi, M., and Bayraktar, S.(2016). Performance Analysis of Banks In Turkey Using Camels Approach Case Study: Six Turkish Banks During 2005 To 2016. Journal of Business Research Turk,10(2), PP. 847-874. https://doi.org/10.20491/isarder.2018.458

8. Hawaldar, I.T., Rahman, H., and Kumar, N. (2017). A Comparison of Financial Performance of Islamic and Conventional Banks in Bahrain. American Scientific Research J. for 
Engineering, Technology, and Sciences, 33(1), PP. 100-110.

https://www.researchgate.net/publication/3179546 $\underline{15}$

9. Hossain, S.A., Islam, M.N., Mahmud, M.S.and Islam, K.M.A.(2017). Evaluation of Financial Performance of Commercial Banks in Bangladesh: Comparative Study Based on CAMEL Approach. The Millennium University Journal, 2(1), PP. 54-77.

10. Huq, S.M. (2017).Performance of the banking industry in Bangladesh: Insights of CAMEL rating. International Journal of Financial Engineering, 4(2), PP. 1-14.

11. Islam, T., \& Ashrafuzzaman, M.(2015). A Comparative Study of Islamic and Conventional Banking in Bangladesh: Camel Analysis. Journal of Business and Technology, 10(1), 7391. https://doi.org/10.3329/jbt.v10i1.26907

12. Khan, A. R. (2008). Bank Management- A Fund Emphasis. First edition, $2{ }^{\text {nd }}$ Print, Ruby publications, Dhaka.PP. 57-60,

13. Majumder, T.H., and Rahman, M.M.(2016). A CAMEL Model Analysis of Selected Banks in Bangladesh. International Journal of Business and Technopreneurship, 6(2), PP. 233-266.

14. Mohiuddin, G. (2014). Use of CAMEL Model: A Study on Financial Performance of Selected Commercial Banks in Bangladesh. Universal Journal of Accounting and Finance, 2(5), 151160. https://doi.org/10.13189/ujaf.2014.020504
15. Naeem B. (2016). To analyze the Comparative Financial Performance Analysis of Islamic and Conventional Banks in Pakistan. Journal of Business \& Financial Affairs,5: 235. https://doi.org/10.4172/2167-0234.1000235

16. Rafiq, R.I. (2016). Determining Bank performance using CAMEL rating: A comparative study on selected Islamic and Conventional Banks in Bangladesh. Asian Business Review, 6(3), PP. 151-160.

17. Rahman, M.Z., and Islam, M.S.(2017). Use of CAMEL Rating Framework: A Comparative Performance Evaluation of Selected Bangladeshi Private Commercial Banks. International Journal of Economics and Finance, 10(1). 120128. https://doi.org/10.5539/ijef.v10n1p120

18. Rashid, M. (2020). The Financial Performance Analysis of Islamic Vs Conventional Banks: An Empirical Study on Bangladesh. International Journal of Science and Business, 4(1), 241-252. https://doi.org/10.5281/zenodo.3710665

19. Shoaib, (2016). Camel analysis of conventional vs. Islamic banking: A case of comparative performance study. Pakistan Journal of Business and Policy Research, 5(1), PP. 43-53.

20. Uddin, M.S., Ahsan, M.K. \& Haque, M.A. (2017).Comparison of Financial Performance of Islamic Banks and Conventional Banks in Bangladesh. ABC Research Alert,5(2), 9-20. https://doi.org/10.18034/abcra.v5i2.313

\footnotetext{
ihttps://www.investopedia.com/terms/i/islamicbanking.asp

iDevelopments of Islamic Banking in Bangladesh, January-March 2019, Islamic Banking Cell, ResearchDepartment, Bangladesh Bank.

iii Bangladesh Bank Annual Report 2018-19

iv Bangladesh Bank Annual Report 2018-19

"Bangladesh Bank Annual Report 2018-19

vi Developments of Islamic Banking in Bangladesh, October-December 2019, Islamic Banking Cell, ResearchDepartment, Bangladesh Bank.
}

Citation: Mahmud A, and Rahman MH. (2020). Evaluation and comparison of financial soundness of islamic and conventional private commercial banks in Bangladesh: a CAMEL approach, Can. J. Bus. Inf. Stud., 2(6), 129-140. https://doi.org/10.34104/cjbis.020.01290140 क्ञ 